\title{
At the interface of syntax and prosody: Differentiating left dislocated and tripartite verbless clauses in Biblical Hebrew ${ }^{1}$
}

\author{
Jacobus A. Naudé \\ Department of Hebrew, University of the Free State, South Africa \\ E-mail: naudej@ufs.ac.za \\ Cynthia L. Miller-Naudé \\ Department of Hebrew, University of the Free State, South Africa \\ millercl@ufs.ac.za
}

\begin{abstract}
The so-called tripartite verbless clause in Biblical Hebrew consists of two nominal phrases and a pronominal element. Three analyses of the pronominal element have been advanced, each with implications for understanding the structure of the sentence. A first approach has been to view the pronominal element as a copular constituent, which serves only to link the two nominal constituents in a predication (Albrecht 1887, 1888; Brockelman 1956; and Kummerouw 2013). A second approach has been to view the pronominal element as the resumptive element of a dislocated constituent (Gesenius, Kautzsch and Cowley 1910; Andersen 1970; Zewi 1996, 1999, 2000; Joüon-Muraoka 2006). A third approach combines the first and second approaches and is represented by the work of Khan $(1988,2006)$ and Holmstedt and Jones (2014). A fourth approach views the pronominal element as a "last resort" syntactic strategy - the pronominal element is a pronominal clitic, which provides agreement features for the subject (Naudé 1990, $1993,1994,1999,2002)$. The pronominal element is obligatory when the nominal predicate is a referring noun phrase - the pronominal clitic is used to prevent ambiguity in the assignment of subject and predicate (see Doron 1986; Borer 1983).

As is well-known in the linguistics literature, cross-linguistically left dislocation involves a "gap" at the boundary between the dislocated constituent and the matrix sentence. In spoken language, this gap may be realized by a small pause or an interjection (Berman and Grosu 1976). In this paper we consider the prosodic evidence that is available from the Masoretic accentual tradition. The Masoretes were Jewish scribes who attempted to preserve the precise reading

\footnotetext{
${ }^{1}$ It is a pleasure to dedicate this article to our teacher, colleague and friend, Johan Oosthuizen. An earlier version of this paper was presented at the Linguistics and Biblical Hebrew Section of the Society of Biblical Literature Annual Meeting (San Antonio, Texas) on 22 November 2016. This work is based on research supported in part by the National Research Foundation of South Africa (Jacobus A. Naudé UID 85902 and Cynthia L. Miller-Naudé UID 95926). The grantholders acknowledge that opinions, findings and conclusions or recommendations expressed in any publication generated by the NRF supported research are those of the authors, and that the NRF accepts no liability whatsoever in this regard.
} 
tradition of the biblical text through the addition of a complex system of "accents" which were superimposed on the traditional Hebrew text between the sixth and the tenth centuries CE. Although the accentual system also was used for cantillation purposes, its complex system of conjunctive and disjunctive accents provides important evidence for prosodic phrasing, which can be utilized for differentiating the role of the pronoun in these two types of sentences which are otherwise structurally identical.

Keywords: Biblical Hebrew, left dislocation, tripartite nominal clause, copula, Masoretic accents, prosody, syntax.

\section{Introduction}

The so-called tripartite verbless clause in Biblical Hebrew consists of two nominal phrases and a pronominal element. As described in the traditional Hebrew grammars, the pronominal element - a third-person independent pronoun, which we refer to as PRON-may appear as either the second constituent or as the third constituent. Example (1) illustrates PRON as the second constituent and (2) illustrates PRON as the third constituent. ${ }^{2}$

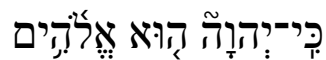

$$
\begin{aligned}
& \text { kî YHWH hiu' 'ělōhîm } \\
& \text { because YHWH PRON:MS God } \\
& \text { "Because the LORD he God." (Psalm 100:3) }
\end{aligned}
$$

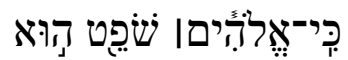

$$
\begin{aligned}
& \text { kî 'ělōhim šōp̄èt hiu' } \\
& \text { because God judge PRON:MS } \\
& \text { "Because God judge he.." (Psalm 50:6) }
\end{aligned}
$$

At least four analyses of the pronominal element have been advanced, each with implications for understanding the structure of the sentence. One approach has been to view the pronominal element as a copular constituent, which serves only to link the two nominal constituents in a predication (Albrecht 1887, 1888; Brockelman 1956). In this analysis, (1) is translated "The LORD is God" and (2) is translated "God is a judge."

A second approach has been to view the pronominal element as the resumptive element of a left dislocated constituent (Gesenius, Kautzsch and Cowley 1910; Andersen 1970; Zewi 1996, 1999, 2000; Joüon-Muraoka 2006). Left dislocation involves a constituent which appears at the front (left) edge of a sentence outside of the sentence proper; the left dislocated constituent is resumed within the sentence by a pronominal element with which it agrees and is co-referential. If the PRON in (1) is understood as the resumed element of a left dislocated constituent, the sentence is translated: "As for the LORD, he is God." The personal name is left dislocated and the co-referential pronoun $h u^{\prime}$ provides resumption within the sentence. Similarly, (2) is translated "As for God, he is a judge."

\footnotetext{
${ }^{2}$ Each Hebrew example includes the Hebrew text (with the Masoretic accents), transliteration, morpheme-bymorpheme gloss, and translation. The glosses follow the Leipzig Glossing Rules with the addition of the following abbreviations: $\mathrm{C}=$ conjunctive accent; $\mathrm{D}=$ disjunctive accent; GENT = gentilic suffix; $\mathrm{MQ}=$ maqqēp $\overline{\mathrm{e}}$ PON $=$ pronominal element. Because the stem formations of Hebrew verbs (e.g. Qal, Niphal, etc.) are not relevant to the linguistic analysis presented here, they are not indicated in the glosses.
} 
A third approach combines these two interpretations of the pronominal element. For example, Holmstedt and Jones (2014) identify some tripartite verbless clauses as left dislocation structures in cases where syntactically there is agreement in number and gender with the resumed element and pragmatically the left dislocated element is the topic in a topic-focus structure. Example (1), for example, they identify as a left dislocation construction: "As for the LORD, he is God." By contrast, in the syntactically identical sentence in (3), they identify the PRON as a copula because they do not view the first constituent as pragmatically functioning as a left dislocated constituent in the larger context. They translate (3) as "The LORD is his portion":

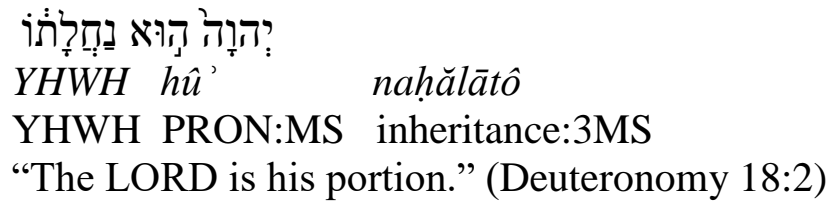

The example in (4) is syntactically identical to (3) and is both syntactically and lexically identical to (1). Holmstedt and Jones, however, classify it as ambiguous because the pragmatics of the first constituent are not clear in the context:

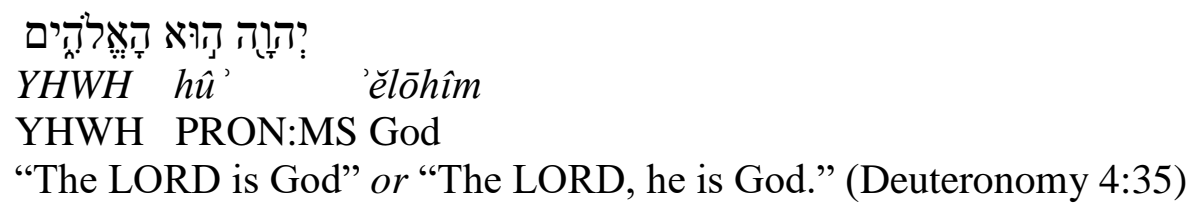

Khan's (2006) approach is similar.

In this paper we present a fourth approach for distinguishing tripartite verbless clauses from verbless clauses with a left dislocated subject constituent based upon the interface between syntax and prosody. This research expands and clarifies the "last resort" analysis of tripartite nominal clauses previously set forth for Biblical Hebrew in Naudé (1990, 1994, 1999), for Qumran Hebrew in Naudé (2002), and for Biblical Aramaic in Naudé (1993, 1994). (The relation of this analysis to editorial theory and complexity theory is described in more detail in Naudé and Miller-Naudé [in preparation]).

The paper is organised as follows: In Section 2 we describe the manuscript traditions of Biblical Hebrew and the prosodic information that can be gleaned from those traditions. In Section 3 we analyse these constructions from the perspective of a "tripartite nominal clause". In Section 4 we analyse these constructions from the perspective a left dislocated constituent which is resumed in the matrix clause. In Section 5 we offer our conclusions.

\section{Biblical Hebrew, Tiberian Hebrew and Prosody}

Biblical Hebrew reflects to a large extent the varieties of Hebrew that were spoken in Israel from the beginning of the Iron Age (about 1200 BCE) to the Hellenistic era (about 165 BCE). The term refers to the form of the language of the Hebrew Bible/Tanak/Old Testament as it appears in the modern scholarly printed editions; it is based on a form of the biblical text found in medieval manuscripts that derives from a school of scholars known as the Masoretes (from the Hebrew verbal root $m s r$ which means "to hand down"). 
Three groups of Masoretes were active, namely in Babylon, Palestine and Tiberias. Their most important task was transmitting the consonantal text with the utmost accuracy. In contrast, earlier scribal activities at Qumran do not reflect the same tradition of precise and conservative copying, but rather exhibit interventions by the scribe (see Tov 2004: 250-254). In addition to these texts a number of biblical texts have been brought to Qumran from elsewhere which are closer to the Septuagint and the Samaritan tradition (Tov 2001: 107). Therefore the Qumran scrolls attest to a multiplicity of texts that co-existed with the one which is found in the Tiberian Masoretic tradition.

Originally Biblical Hebrew writing consisted of consonants only. In order to prevent the loss of the correct pronunciation, which was transmitted orally, around $600 \mathrm{CE}$ the Masoretes began to devise a system of signs to record and standardise the received pronunciation. The work of the Masoretes was continued for many centuries by a large number of scholars. The most important system is known as the Tiberian Masoretic system and is the product of the work of the Ben Asher family in Tiberias about $900 \mathrm{CE}$. The consonantal text that was incorporated into the Tiberian Masoretic tradition is a textual tradition that was transmitted with precision since at least the third century BCE. In addition to the consonantal text, the Tiberian Masoretic tradition concerns the layout of the text, indications of divisions into paragraphs, vocalisation, accent signs, marginal notes, treatises and the orally transmitted reading tradition. The accent and vocalisation signs, but not the reading tradition that the signs represented, as well as the majority of textual notes and treatises were developed by the Masoretes. The other components were inherited from earlier traditions (Khan 2013: 3-4).

The highly meticulous work of the Masoretes gave rise to the term for the careful biblical text that they produced, the Masoretic text. The earliest complete text in which this system is preserved is the Leningrad Codex from the year 1008, which is now housed in the Russian National Library in St Petersburg. The scientific editions of the Hebrew Bible in the series of Biblia Hebraica use the Leningrad Codex as their base text, specifically the third edition of the Biblia Hebraica Kittel (1937), Biblica Hebraica Stuttgartensia (1977) and Biblia Hebraica Quinta (since 2004). The Biblical Hebrew described in this article is thus, strictly speaking, the Masoretic Biblical Hebrew of the Ben Asher family. Therefore, some scholars prefer the term "Tiberian (Biblical) Hebrew" instead of "Biblical Hebrew."

The accent system which the Masoretes developed indicates the stressed syllable of a word, which can be crucial to determine the correct interpretation, for example ša $\bar{a} \underline{b} \hat{u}$ "they captured" (Genesis 34:29) but šá $\bar{a} \underline{u}$ "they returned" (Joshua 2:22). The accent system also indicates the places where long or short pauses occur in a clause and which words belong together (Yeivin 1980: 158; Khan 2013: 37). There are two accent systems - one for the prose sections and one for three poetic books, namely Psalms, Job and Proverbs (Yeivin 1980: 157-158). The most important accent signs are, however, more or less the same for both. Two groups of accent signs may be distinguished, namely conjunctive (joining) accents and disjunctive (separating) accents. They are used as follows: The accent sign indicates the position of the stressed syllable in a word. In Biblical Hebrew the final syllable is usually accented; in certain cases also the penultimate is accented. The accent sign is normally placed above or below the first consonant of the accented syllable. In some cases accent signs are placed at the beginning or end of the word-these are the so-called prepositive and postpositive accents, respectively. The conjunctive and disjunctive accents often follow each other in a fixed order. The resultant sequence of accents was used to group together the words of the Biblical Hebrew text. This 
grouping of words facilitated the recitation of the Hebrew Bible in the synagogues and was thus similar to punctuation in modern publications.

It was the achievement of the Masoretes to create a written notation to record a tradition that they received from an earlier period. The disjunctive signs, which exist both in the Babylonian and Tiberian systems, have a double function of punctuation and melody (Ofer 2016: 192). The disjunctive accents mark a break and require the reader to pause slightly. The various disjunctive accents express different degrees of pause. The musical function combines with punctuation to give a division of the verse into syntactic units (Ofer 2016: 192).

Khan (2013: 39-40) provides two examples where disjunctive accents serve to indicate which of two syntactic interpretations should be followed. Although he describes the accents as indicating syntactic divisions (similarly, Ofer 2016: 192), it is rather the case that they indicate prosodic phrases (see Dresher 1984), some of which correspond with syntactic phrase structure.

The first example is given in (5):

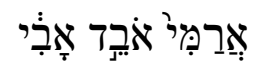

Aram:GENT PTCP:MS:become.lost/perish father-my

"An Aramaean was seeking to destroy my father." (Deuteronomy 26:5)

* "A wandering Aramaean was my father."

The disjunctive accent on the first word of the clause indicates that it is prosodically separated from the following participle. This means that the first two words should not be interpreted as noun and attributive participle, which would normally be indicated as one intonational phrase with a conjunctive accent. Instead, the two words should be interpreted as subject and predicate. This interpretation is found in Targum Onqelos (an ancient Aramaic translation of the Hebrew Bible) and midrashic (i.e. exegetical) literature from which it was incorporated into the Passover liturgy (the Haggadah); it is also reflected in the translation of the Latin Vulgate. The second interpretation is found in many modern versions, such as the Revised Standard Version, which did not take the accents into account: "A wandering Aramaean was my father."

In the second example described by Khan, multiple disjunctive accents are found. We have indicated them in the gloss hierarchically - a D0 accent is a strongly disjunctive accent that marks either the end of the verse or the greatest pause within the verse, a D1 accent is a slightly less strong disjunctive accent that indicates the biggest break within half of the verse, a D2 accent is an even less strong disjunctive accent.

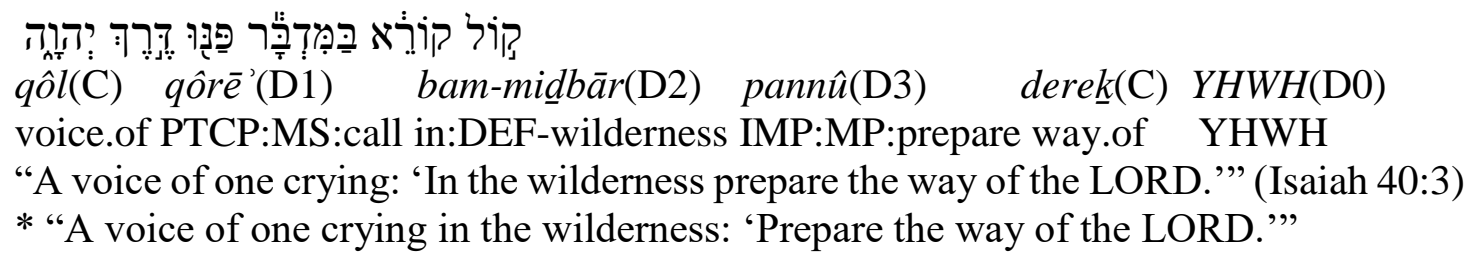

In this sentence the accents mark a major intonational pause after the word qôrē' ("crying"), which correlates with a syntactic break, namely, the beginning of the quotation. This interpretation means that the prepositional "in the wilderness" belongs to the quotation that 
follows and is topicalised within its sentence (the topicalised phrase is separated from its sentence by a smaller intonational pause). The interpretation reflected by the accents corresponds to what is found in Rabbinic literature and the Aramaic Targums, and is followed by many modern English translations. By contrast, the KJV (King James Version) translates: "The voice of him that crieth in the wilderness, Prepare ye the way of the LORD."3

The conjunctive accents, which exist only in the Tiberian system, occur between the disjunctive accents; all of the conjunctive accents express the same degree of connection (Khan 2013: 38). They have only a musical function: their melody fits in with the melody of the following disjunctive sign, where a sequence of two or three conjunctive signs precedes a disjunctive sign resulting in considerable musical variety (Ofer 2016: 192). Short words are cliticised to the following word; they form a single musical unit with the short word joined to the following

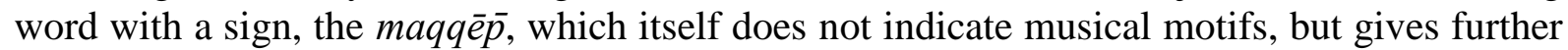
indication of how the music of the chant should be related to the words of the text (Yeivin 1980: 157).

\section{The Tripartite Verbless Clause}

We begin by identifying the syntactic features of the tripartite verbless clause and its pronominal element. We will make two separate arguments against PRON as a copula-one from a generative perspective and one from a typological perspective. From a generative perspective, the tripartite verbless clause is like the verbless clause in that both kinds of clauses lack an overt form of the verb hāy $\hat{a}$ ("be"). If the pronominal element is interpreted as a copula, then it should exhibit similar syntactic roles to the verb hāyâ. This, however, does not seem to be the case in many ways. First, $h \bar{a} y \hat{a}$ can optionally appear in constructions with the participle, but PRON cannot. Second, PRON cannot precede the subject of a tripartite verbless clause, but $h \bar{a} y \hat{a}$ can precede the subject of an existential clause. Third, hāyâ allows pro-drop (the nonexpression of an independent subject in a predication), but tripartite verbless clauses require the subject to be explicitly expressed. Fourth, existential sentences with hāyâ typically have noun phrases, prepositional phrases and adjectival phrases as the complement predicate. Tripartite verbless clauses usually have noun phrases and occasionally prepositionally phrases as the predicate. Tripartite verbless clauses thus are primarily used as specificational clauses involving two noun phrases; they thus have a reduced function from existential predications with hââa. We conclude, therefore, that PRON in the tripartite verbal clause is not a copula and it does not occupy an argument position within the predication.

Let us now consider whether PRON should be identified as a copula from a typological point of view. Among the languages of the world, the main differentiation is between languages in which no overt item marks the relation between the nominal subject and the nominal predicate (in other words, a zero copula) and languages in which an overt item marking the relation between the nominal subject and the nominal predicate is required. Intermediate positions on the continuum involve cases where the use of a zero copula is limited by some sort of condition. A common condition is the distinction between the use of a zero copula for present tense and an overt copula for non-present tense. This is the case in Biblical Hebrew, where hââa is used

\footnotetext{
${ }^{3}$ It is not clear whether the translators of the KJV did not pay attention to the accents or whether they were harmonising with New Testament citations of the Isaiah verse, e.g. Matthew 3:3 "For this is he that was spoken of by the prophet Esaias, saying, The voice of one crying in the wilderness, Prepare ye the way of the Lord, make his paths straight."
} 
for past or future time and a zero strategy (non-overt copula) is used for present tense (see, e.g. Gesenius, Kautzsch and Cowley 1910: 454; Joüon 1947: 471; Waltke and O'Connor 1990: 72; Zewi 2013: 836). Although a pro-copula (that is, a demonstrative pronoun or a personal pronoun) may be used as a copula in some languages, its use is usually "obligatory in nominal predication" (Stasson 2005: 487). This is not the situation in Biblical Hebrew, however, where only a small percentage of verbless predications include a personal pronoun in addition to the nominal subject and nominal predicate. In other words, it is not PRON which creates the predication between two nominal elements; PRON therefore cannot be a copula (contra Kummerow 2013).

Rather than viewing PRON as a copula and thus as part of the predicate, PRON has features that indicate that it is a clitic-like element that relates to the subject constituent. First, we note that PRON regularly appears immediately following the subject. It never precedes the subject and it cannot be moved out of the sentence. Second, unlike the resumptive pronoun in a sentence with a dislocated constituent, PRON agrees with its subject in gender and number, but not in person-PRON is always third person. Third, PRON fits the criteria of Zwicky 1977 and 1985 concerning the identification of clitics. Clitics typically do not carry stress, cannot occur in isolation, cannot stand in first position in a sentence and cannot form an independent noun phrase node but instead form part of the node to which it cliticises. We can illustrate these features of PRON in (7):

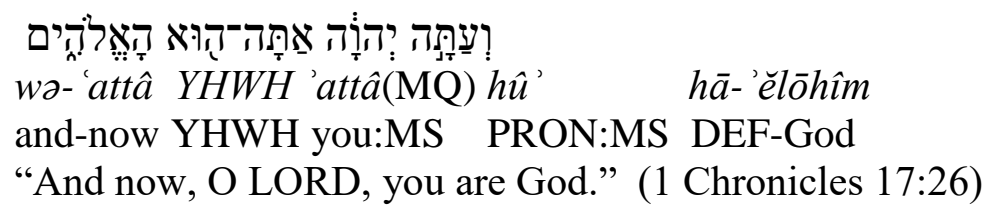

The use of PRON after the second masculine singular pronoun is especially prevalent after a vocative within direct speech. Note that the PRON is joined with a maqqēp (a hyphen-like Masoretic symbol, abbreviated MQ in the gloss) to the subject pronoun 'attâ, thus forming one accentual unit; 'attâ does not have its own Masoretic accent. (This was already shown in Naudé 1993 and 1994 but was not taken note of by researchers afterwards.)

In cases where PRON is not joined with a maqqēp to the preceding subject, PRON nonetheless is joined prosodically by a conjunctive accent on the preceding subject:

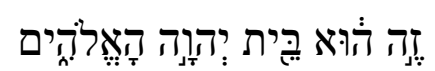

$$
\begin{aligned}
& z e h(\mathrm{C}) h \hat{u} \text { '(D) bêt } \quad Y H W H \quad h \bar{a} \text {-'ělōhîm }
\end{aligned}
$$

this PRON:MS house.of YHWH DEF-God

"This is the house of the LORD God." (1 Chronicles 22:1)

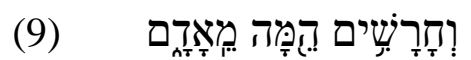

we-ḥārāš-îm(C) hèmmâ $m \bar{e}-{ }^{-} \bar{a} \underline{d} a \bar{m}$

and-craftsman-PL PRON:MPL from-human

"The craftsmen are human (lit. from humankind)." (Isaiah 44:11) 


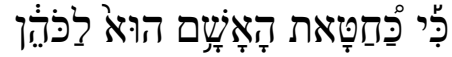

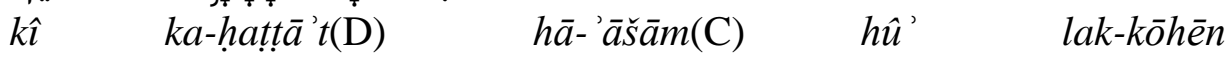

Because like:DEF-sin.offering DEF-guilt.offering PRON:MS to:DEF-priest

"For, like the sin offering, the guilt offering belongs to the priest." (Leviticus 14:13)

In this example, the adjunct prepositional phrase "like the sin offering" is topicalised at the beginning of the sentence.

The presence of PRON is optional - it is used to prevent ambiguity in the assignment of subject and predicate (see Doron 1986; Borer 1983). Put differently, the pronominal element allows Case assignment of the subject to one of the two nominal phrases within the verbless clause. Because verbless clauses in Biblical Hebrew are particularly vulnerable to syntactic ambiguity, the addition of PRON to form a tripartite verbless clause removes ambiguity in the following contexts.

First, in direct speech, vocative expressions may be confused with nominal predications. In these contexts, the addition of PRON serves to discriminate a nominal predication from vocative epithets by indicating which nominal element is the subject. In (11), PRON indicates that the preceding independent personal pronoun 'attâ should be understood as the subject rather than as appositional to the following noun phrase. In other words, malkî ("my king") cannot be understood as a vocative interposed between the pronominal subject ("you") and 'élōhîm ("God") as the nominal predicate:

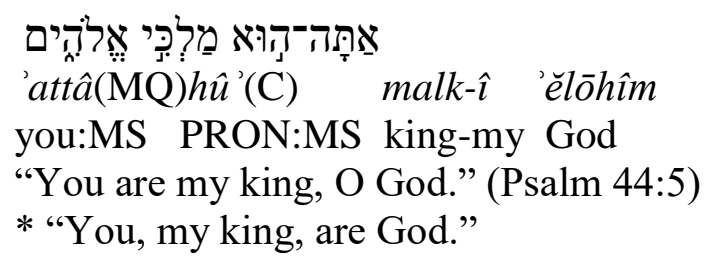

Second, when the nominal subject and nominal predicate could be understood as an unmarked relative clause, PRON serves to indicate that one of the nominal elements is instead the subject of an independent clause:

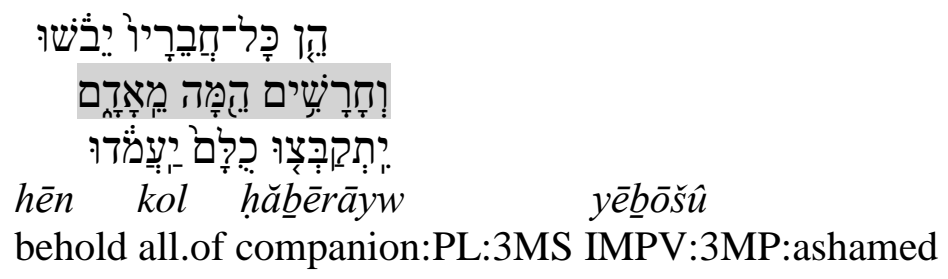

"Behold, all of its companions will be ashamed.

The craftsmen are from humankind. 
* The craftsman (who are) human

Let all of them be assembled, let them stand up..." (Isaiah 44:11)

The PRON hemmmâ forces a reading "the craftsmen are from humankind" rather than "the craftsmen (who are) human" as the subject of the following verbs.

Similarly, when the nominal predicate is a preposition phrase, PRON may be used to ensure that the prepositional phrase is not read as an unmarked relative clause. In (13), the PRON forces the reading "the guilt offering belongs to the priest" rather than "the guilt offering (which) belongs to the priest."

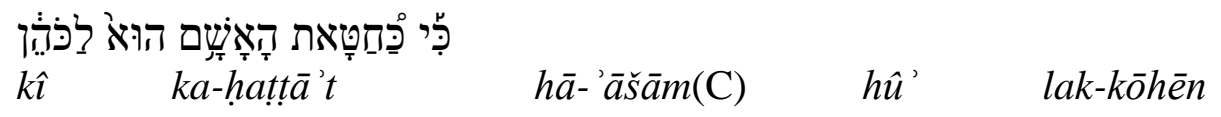

Third, when the nominal subject is itself a demonstrative pronoun, PRON indicates unambiguously that it is the subject:

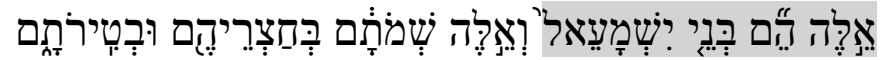

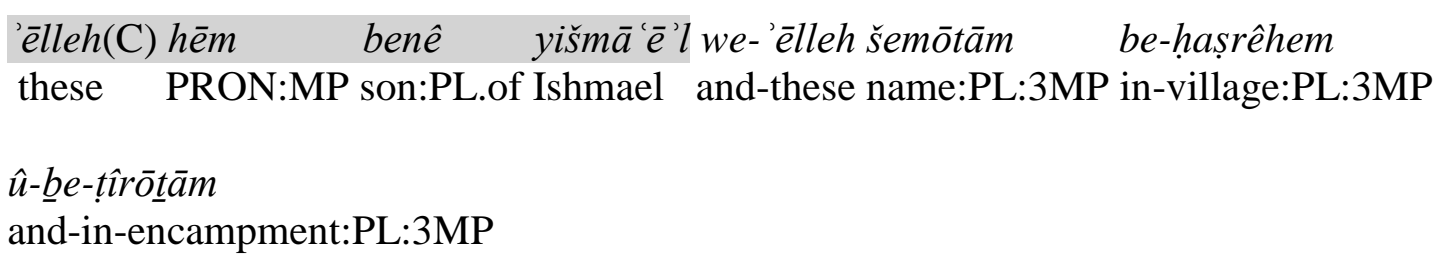

"These are the sons of Ishmael and these (are) their names by their villages and by their encampments." (Genesis 25:16)

The first verbless sentence has the masculine plural PRON hèm following 'êlleh as the subject. The following verbless sentence has a similar structure and PRON is not needed to assist in designating the subject.

Similarly, PRON may be used after an independent personal pronoun which functions as an anaphoric pronoun to a preceding indefinite noun phrase:

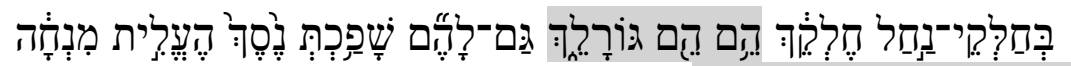

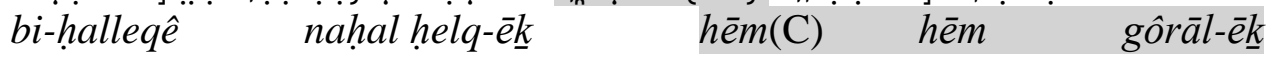

$$
\begin{aligned}
& \text { with-stone:PL:of valley portion-your:FS PRON:3MP PRON:3MP lot-your:FS }
\end{aligned}
$$

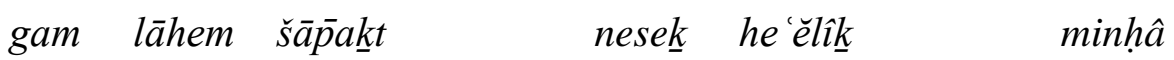

$$
\begin{aligned}
& \text { indeed to:3MP PFV:2FS:pour.out libration PFV:2FS:brought grain.offering }
\end{aligned}
$$

"With the smooth stones of the valley is your portion. They are your lot. Indeed to them you have poured out libations, you have brought a grain offering." (Isaiah 57:6) 
Fourth, the use of PRON may be used to indicate that an adjectival constituent should be understood as the subject rather than the predicate of the predication:

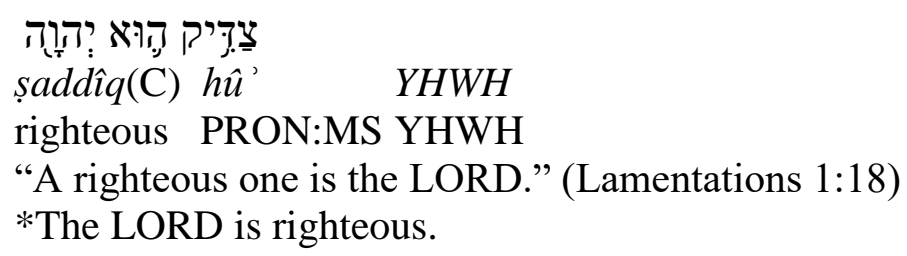

The conjunctive accent on the first constituent and the PRON which follows it indicates that the sentence should be interpreted as "A righteous one is the LORD" and not as "The LORD is righteous" (with the adjective as a predicate).

One very interesting feature of tripartite verbless clauses is the fact that $\mathrm{WH}$-interrogatives trigger inversion of the subject and predicate constituents:

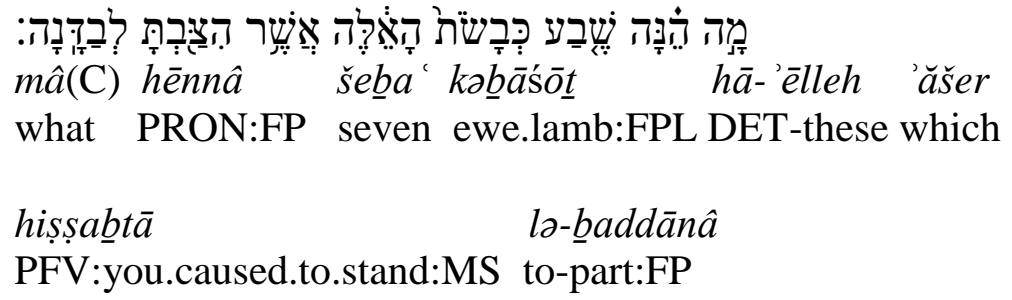

"What are these seven ewe lambs which you have set apart by themselves?" (Genesis 21:29)

The sentence exhibits agreement in gender of PRON with the subject. The interrogative $m \hat{a}$ representing the predicate nominal occurs in first position and has triggered the inversion of the subject constituent and the PRON which follows it in indicative sentences. The sentence is not an example of left dislocation (contra Holmstedt and Jones 2014: 77).

Similarly, in (18) the interrogative triggers inversion of the subject and PRON, but in addition the subject has become topicalised and moved to the beginning of the sentence:

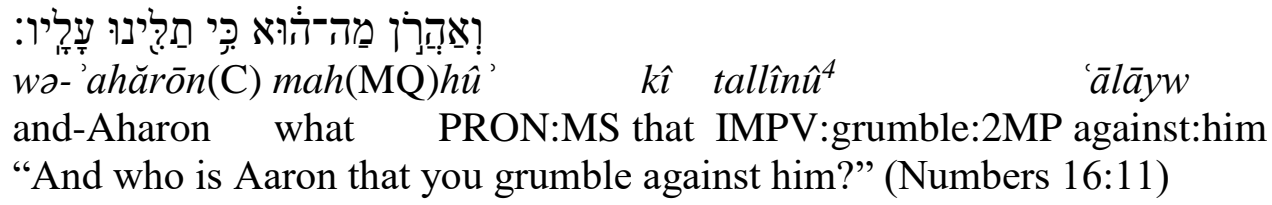

In this example, the fact that all three constituents of the tripartite verbless clause are joined together, first with a conjunctive accent and then with a maqqe $\bar{p}$, means that the sentence cannot be understood as a left dislocation structure (contra Holmstedt and Jones 2014: 78).

We have seen that tripartite verbless clauses can be identified both by syntactic and prosodic features. Syntactically, PRON occurs as the second constituent, immediately after the subject

\footnotetext{
${ }^{4}$ We follow the qere reading (the marginal "read" reading) as opposed to the ketiv ("written" reading) for this verb, but the difference between the two readings does not affect the linguistic analysis.
} 
in indicative sentences and interrogative yes-no sentences. In interrogative sentences with a WH-question, there is inversion of subject and PRON. The PRON is optional and is used to make explicit the subject of the verbless predication.

Prosodically, the subject and its PRON form one intonational unit. The PRON may lack stress and be joined to the subject with a maqqēp or the PRON may be joined to the subject with a conjunctive accent. These prosodic features serve to disambiguate PRON from a full-fledged independent pronoun as well as from the resumptive element of a left dislocation construction. In addition, note that the traditional description of a tripartite verbless clause as having the pronominal element either in second or third position in the sentence is incorrect - a tripartite verbless clause never has PRON in third position, except in a $\mathrm{WH}$-interrogative sentence as a result of inversion.

\section{Left dislocation}

We turn now to verbless clauses with left dislocation of the subject constituent. Left dislocation involves a constituent that occurs outside of the matrix sentence and is resumed by a pronominal element within the sentence. Syntactically, the sentence boundary may be indicated by a sentence adverbial such as $h \breve{a}-l \bar{o}^{\prime}$ (the interrogative marker followed by the negative particle):

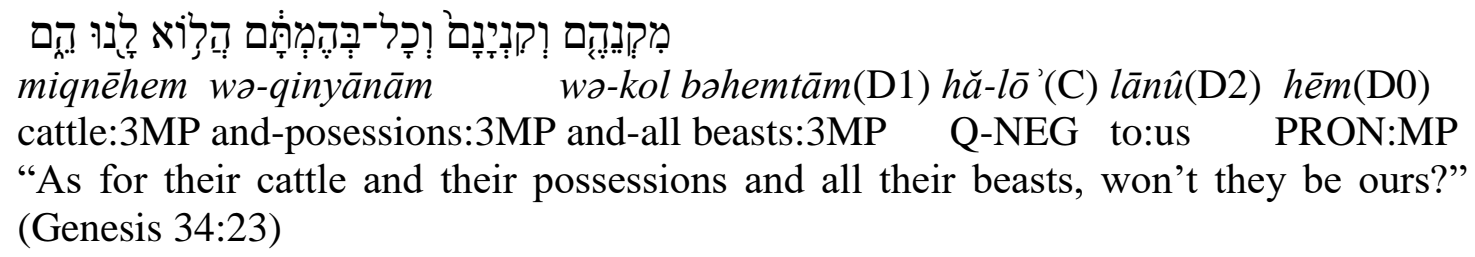

The left dislocated subject is separated from the main sentence both syntactically and prosodically by a strong disjunctive accent. The subject is resumed within the sentence with the third person plural pronoun hem. Note that the pronoun is a fully-fledged pronounsyntactically it functions as the subject of the sentence and prosodically it has its own accent and does not cliticise to a preceding constituent. In these respects, the pronoun in left dislocation constructions is distinct from the PRON of tripartite verbless clauses.

Similarly, when the sentence is negated, the negative marker stands at the beginning of the matrix sentence:

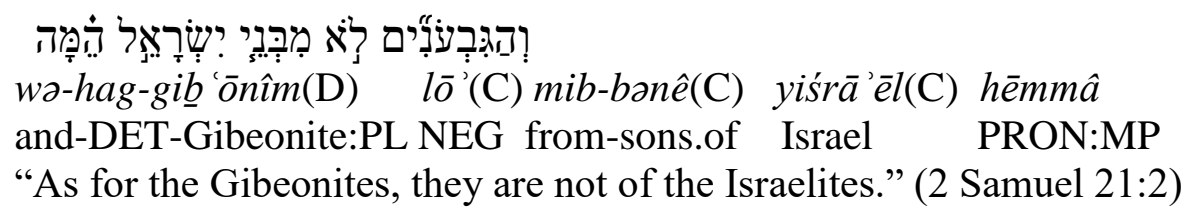

In addition to syntactic indications of the sentence boundary, there are prosodic indications as well. Cross-linguistically left dislocation involves a "gap" at the boundary between the dislocated constituent and the matrix sentence. In spoken language, this gap may be realized by a small pause or an interjection (Berman and Grosu 1976) which sets apart the dislocated element with its own intonational contour (see also Korchin 2015: 14-15). In the Masoretic tradition of the Hebrew Bible, left dislocated constituents are consistently set apart from the 
sentence with a disjunctive accent, as can be seen in the examples here. The same is true when the sentence boundary is not syntactically indicated by a sentence adverbial, as in (21):

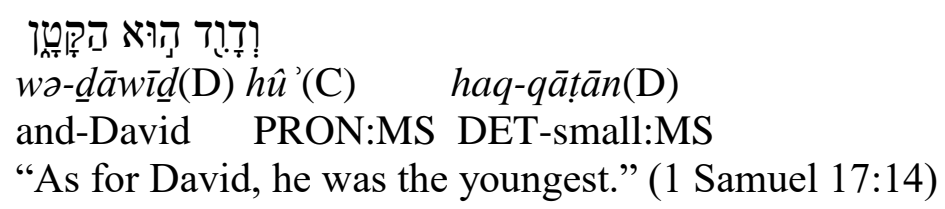

In left dislocation structures, the order of constituents within the matrix sentence may be in predicate - subject order rather than subject — predicate order, depending upon the information structure of the sentence. In (22), the prepositional predicate is placed in first position within the matrix sentence to provide contrastive focus - the land of Egypt is before you, not someone else:

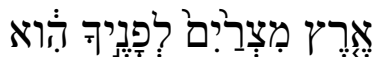

$$
\begin{aligned}
& \text { 'ereș }(\mathrm{C}) \quad \text { mișrayim(D) lapāaneyka }(\mathrm{C}) h \hat{\imath}^{25} \\
& \text { land:FS.of Egypt to-faces-your PRON:FS } \\
& \text { "As for the land of Egypt, it is before you." (Genesis 47:6) }
\end{aligned}
$$

\section{Conclusions}

In conclusion, we have seen that the tripartite verbless clauses and left dislocated verbless clauses are structurally distinct, both syntactically and prosodically. Traditional attempts to analyse all verbless sentences with three constituents in which one constituent is morphologically a pronoun resulted in incorrect identifications of the pronominal element as either a copula or a resumptive pronoun.

The analysis by Holmstedt and Jones (2014) attempted to distinguish tripartite verbless clauses from left dislocated verbless clauses by examining both the syntax and the semantics/pragmatics of the construction within its textual context. The analysis presented here relies upon the vocalisation tradition as preserved by the Masoretic accentual system to differentiate the two constructions rather than upon our ability to discern the semantics or pragmatics of the initial constituent of the construction within the biblical text. In many examples, our analysis confirms that of Holmstedt and Jones - for example, sentence (1) does present an example of left dislocation. In far fewer examples, our analysis is not identical. Of the left dislocation examples they identify, $10 \%$ are examples of "last resort" pronouns or of simple verbless clauses. ${ }^{6}$ Of the 38 examples they identify as "copular" (which we see rather as the use of a "last resort pronoun"), 13 examples (34\%) are instead examples of left dislocation. ${ }^{7}$ Furthermore, all of their "ambiguous" examples (including example [4] above and Appendix C) can be clearly identified as either left dislocation (12 examples) or tripartite verbless clauses

\footnotetext{
${ }^{5}$ Reading the pronoun with the qere ("reading" tradition) rather than the ketiv ("written tradition").

${ }^{6}$ The following verses that Holmstedt and Jones (2014: 77-82) identify as left dislocation should rather be identified as tripartite verbless clauses: Genesis 21:29; 30:33; Exodus 39:5; 39:14; Numbers 16:11; Isaiah 44:11; 57:6; Psalm 39:5; Job 41:3; Nehemiah 8:9. Genesis 37:27 is a simple verbless clause.

${ }^{7}$ The following verses that Holmstedt and Jones (2014: 83-85) identify as "copular examples" (which we see rather as verbless clauses with a "last resort" pronominal element) should rather be identified as left dislocated verbless clauses: Genesis 2:19; 15:2; 36:8; 42:6; Leviticus 25:33; Deuteronomy 10:9; 10:17-18; 12:23; 18:2; Joshua 13:14; 13:33; Isaiah 9:14; Zephaniah 2:12.
} 
with a "last resort" pronoun ( 1 example) on the basis of their Masoretic vocalisation. ${ }^{8}$ The fact that most of the 13 examples identified by Holmstedt and Jones as "ambiguous" were understood by the Masoretes as left dislocated verbless clauses, may mean that the semantic/pragmatic features of the left dislocated constituent were somewhat different in Biblical Hebrew than in English. Or it may mean that it is simply difficult to be certain about the semantic/pragmatic import of an ancient written text, the attempts by Korchin (2015) notwithstanding. It is important to note, however, that in the vast majority of cases, attention to the prosodic features of these constructions provides additional confirmation for distinguishing between the two constructions.

In this article, we have argued that the tripartite verbless clauses and left dislocated verbless clauses reflect two different underlying structures and two very different pronominal elements. Tripartite verbless clauses use a cliticised pronominal element after the subject as a "last resort" strategy for unambiguously identifying the subject of a verbless sentence. Left dislocated verbless sentences have a subject constituent outside of the matrix sentence which is resumed within the sentence proper. The pronominal element within tripartite verbless clauses is always prosodically joined to its subject, either with a maqqēp or with a conjunctive accent. By contrast, the pronominal element within left dislocated verbless clauses is a fully-fledged pronoun which functions as an argument in the sentence and the left dislocated element is prosodically separated from the matrix sentence with a disjunctive accent. As a result, verbless clauses with a dislocated element may have the pronominal element as the second or third constituent in the sentence, in contrast to tripartite verbless sentences in which PRON always occurs after the subject.

The evidence of the Masoretic vocalisation, in which every accent is either conjunctive or disjunctive, provides a way to identify a pronominal clitic (the PRON of the tripartite verbless clause), which is joined to its subject with a conjunctive accent. It also provides a way to identify a left dislocated constituent, which is separated prosodically and intonationally from the matrix sentence, by its disjunctive accent. By differentiating the two constructions on the basis of their morphological, syntactic and prosodic features, it is possible to translate and interpret these structures in the Hebrew Bible more accurately and insightfully.

\section{References}

Albrecht, C. 1887. Die Wortstellung im hebräischen Nominalsatze. Zeitschrift für die alttestamentliche Wissenschaft 7: 218-224.

Albrecht, C. 1888. Die Wortstellung im hebräischen Nominalsatze: Teil II. Zeitschrift für die alttestamentliche Wissenschaft 8: 249-263.

Andersen, F. I. 1970. The Hebrew verbless clause in the Pentateuch. Journal of Biblical Literature Monograph Series 14. New York and Nashville: Abingdon.

\footnotetext{
${ }^{8}$ The following examples that Holmstedt and Jones (2014: 85-86) identify as "ambiguous examples" should be understood as left dislocated constructions: Leviticus 20:21; Deuteronomy 4:35; 4:39; 7:9; Joshua 2:11; 1 Kings 8:60; 18:39; Qoheleth 1:9; Daniel 8:21; 2 Chronicles 33:13. Only Qoheleth 1:17 should be identified as a tripartite verbless clause with a "last resort" pronominal element.
} 
Baastian, F. J. 2000. Existential clauses in Qumran Hebrew. In T. Muraoka and J. F. Elwolde (eds.) Diggers at the well: Proceedings of a Third International Symposium on the Hebrew of the Dead Sea Scrolls and Ben Sira. Studies on the Texts of the Desert of Judah 36. Leiden: Brill. pp. 1-11.

Berman, R. and A. Grosu. 1976. Aspects of the copula in Modern Hebrew. In P. Cole (ed.) Studies in Modern Hebrew syntax and semantics. Amsterdam: North-Holland. pp. 265-285.

Borer, H. 1983. Parametric syntax. Dordrecht: Foris.

Brockelman, C. 1956. Hebräische Syntax. Neukirchen-Vluyn: Neukirchener Verlag.

Doron, E. 1986. The pronominal "copula" as agreement clitic. Syntax and Semantics 19: 313332.

Dresher, B. E. 1984. The prosodic basis of the Tiberian Hebrew system of accents. Language 70(1): $1-52$.

Geiger, G. 2012. Das hebräische Partizip in den Texten aus der judäischen Wüste. Studies on the Texts of the Desert of Judah 101. Leiden: Brill.

Gesenius, W., E. Kautzsch and A. E. Cowley. 1910 Gesenius' Hebrew grammar. ${ }^{\text {nd }}$ English edition. Oxford: Clarendon.

Holmstedt, R. D. and A. R. Jones. 2014. The pronoun in tripartite verbless clauses in Biblical Hebrew: Resumption for left-dislocation or pronominal copula? Journal of Semitic Studies 59(1): 53-89.

Joüon, P. 1947. Grammaire de l'Hébreu biblique. Rome: Editrice Pontificio Istituto Biblico.

Joüon, P. and T. Muraoka. 2006. A grammar of Biblical Hebrew. 2d edition. Rome: Pontifical Biblical Institute.

Khan, G. 1988. Studies in Semitic syntax. London Oriental Series 38. London: Oxford University Press.

Khan, G. 2006. Some aspects of the copula in North West Semitic. In S. E. Fassberg and A. Hurvitz (eds.) Biblical Hebrew in its Northwest Semitic setting: Typological and historical perspectives. Jerusalem: The Hebrew University Magness Press / Winona Lake: Eisenbrauns. pp. 155-176.

Khan, G. 2013. A short introduction to the Tiberian Masoretic Bible and its reading tradition. 2nd edition. Gorgias Handbooks 25. Piscataway, NJ: Gorgias.

Korchin, P. 2015. Suspense and authority amid Biblical Hebrew front dislocation. Journal of Hebrew Scriptures Volume 15, Article 1 DOI:10.5508/jhs.2015.v15.a1. 
Kummerow, D. 2013. Object predication in Tiberian Hebrew: A typological approach to the nonverbal copula. Kleine Untersuchungen zur Sprache des Alten Testaments und seiner Umwelt 19: $1-135$.

Miller, C. L. (ed.) 1999. The verbless clause in Biblical Hebrew: Linguistic approaches. Linguistic Studies in Ancient West Semitic 1. Winona Lake: Eisenbrauns.

Naudé, J. A. 1990. A syntactic analysis of dislocation in Biblical Hebrew. Journal of Northwest Semitic Languages 16: 115-130.

Naudé, J. A. 1993. Aspects of the verbless clause in Biblical Aramaic. South African Journal of Linguistics 18: 49-63.

Naudé, J. A. 1994. The verbless clause with pleonastic pronoun in Biblical Aramaic. Journal for Semitics 6: 74-93.

Naudé, J. A. 1999. Syntactic aspects of co-ordinate subjects with independent personal pronouns. Journal of Northwest Semitic Languages 25(2): 75-99.

Naudé, J. A. 2002. The third person pronoun in tripartite verbless clauses of Qumran Hebrew. In H. J. Simon and H. Wiese (eds.) Pronouns: Representation and grammar. Amsterdam: Benjamins. pp. 161-182.

Naudé, J. A. and C. L. Miller-Naudé. In preparation. Complexity theory. In J. A. Cook and R. D. Holmstedt (eds.) Linguistics for hebraists and biblical scholars. Linguistic Studies in Ancient West Semitic. Winona Lake: Eisenbrauns.

Ofer, Y. 2016. The Tiberian tradition of reading the Bible and the masoretic system. In W. R. Garr and S. E. Fassberg (eds.) A handbook of Biblical Hebrew. 2 volumes. Volume 1: Periods, Corpora, and Reading Traditions. Winona Lake: Eisenbrauns. pp. 187-202.

Stasson, L. 2005. Zero copula for predicate nominals. In M. Haspelmath, M. S. Dryer, D. Gil, B. Comrie (eds.) World atlas of language structures. Oxford: Oxford University Press. pp. 486487.

Van Hecke, P. 2008. Constituent order in existential clauses. In J. Joosten and J.-S. Rey (eds.) Conservatism and innovation in the Hebrew language of the Hellenistic Period: Proceedings of a Fourth International Symposium on the Hebrew of the Dead Sea Scrolls and Ben Sira. Studies on the Texts of the Desert of Judah 73. Leiden: Brill. pp. 61-78.

Van Peursen, W. 1999. Negation in the Hebrew of Ben Sira. In T. Muraoka and J. F. Elwolde (eds.) Sirach, scrolls, and sages: Proceedings of a Second International Symposium on the Hebrew of the Dead Sea Scrolls, Ben Sira, and the Mishnah, held at Leiden University, 15-17 December 1997. Studies on the Texts of the Desert of Judah 33. Leiden: Brill. pp. 223-243.

Waltke, B. K. and M. O’Connor. 1990. Introduction to Biblical Hebrew syntax. Winona Lake: Eisenbrauns. 
Yeivin, I. 1980. Introduction to the Tiberian Masorah. Translated and edited by E. J. Revell. Society of Biblical Literature Masoretic Studies 5. Missoula, MT: Scholars Press.

Zewi, T. 1996a. Subordinate sentences involving prolepsis in Biblical Hebrew. Journal of Semitic Studies 41: 1-20.

Zewi, T. 1996b. The definition of the copula and the role of 3rd independent personal pronouns in nominal sentences of Semitic languages. Folia Linguistica Historica 17(1-2): 41-55.

Zewi, T. 1999. Tripartite nominal clauses and appositional clauses in Biblical Hebrew. Ancient Near Eastern Studies 36: 36-47.

Zewi, T. 2000. Is there a tripartite nominal sentence in Biblical Hebrew? Journal of Northwest Semitic Languages 26(2): 51-63.

Zewi, T. 2013. Nominal clause. In G. Khan (ed.) Encyclopedia of Hebrew language and linguistics, vol. 2. Leiden: Brill. pp. 830-839.

Zwicky, A. M. 1977. On clitics. Bloomington: Indiana University Linguistics Club.

Zwicky, A. M. 1985. Clitics and particles. Language 61(2): 283-305. 